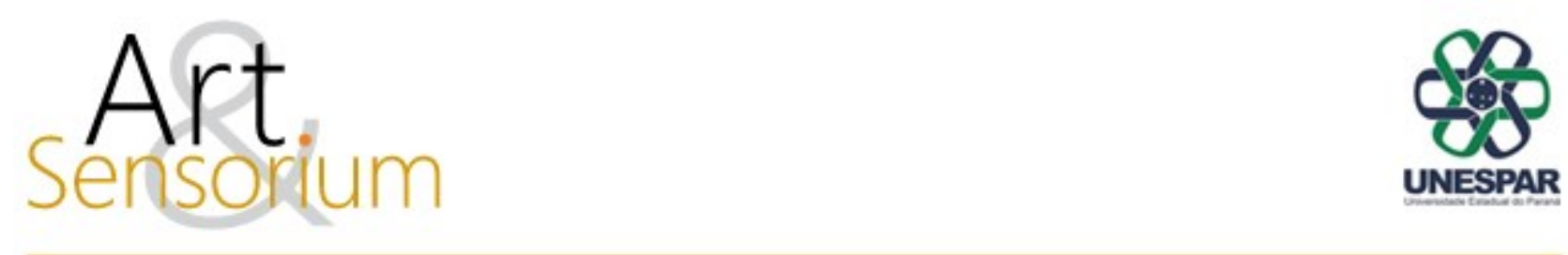

\title{
EM BUSCA DE CURITIBA PERDIDA: DA LITERATURA AO CINEMA, UMA TRANSPOSIÇÃO CINEMATOGRÁFICA
}

DOI: https://doi.org/10.33871/23580437.2021.8.2.093-104

Estevan Alexandre da Silveira ${ }^{1}$

Salete Paulina Machado Sirino ${ }^{2}$

RESUMO: Este artigo é o resultado de uma pesquisa acadêmica sobre a transposição do conto "Em busca de Curitiba perdida", do escritor Dalton Trevisan, para a linguagem cinematográfica, do documentário fílmico. As relações intersemióticas entre o texto literário e o texto cinematográfico são abordadas neste artigo, com o objetivo de revisitar tanto a tradução entre as linguagens literário e cinematográfica, quanto sua incomensurabilidade cognitiva.

Palavras-chave: cinema, conto, Dalton Trevisan, semiótica.

\section{IN SEARCH OF THE LOST CURITIBA: FROM LITERATURE TO FILM, A CINEMATIC TRANSPOSITION}

\begin{abstract}
This article is the result of an academic research on the transposition of the short story "In search of lost Curitiba", by the writer Dalton Trevisan, for the cinematographic language, of the film iced documentary. The intersemiotic relationships between literary text and cinematic text are addressed in this article, with the objective of revisiting both the translation between literary and cinematographic languages and their cognitive imcommensurability.
\end{abstract}

Keywords: cinema, short story, Dalton Trevisan, semiotics.

\section{EN BUSCA DE LA CURITIBA PERDIDA: \\ DE LA LITERATURA AL CINE, UNA TRANSPOSICIÓN CINEMATOGRÁFICA}

RESUMEN: Este artículo es el resultado de una investigación académica sobre la transposición del cuento "En busca de curitiba perdida", del escritor Dalton Trevisan, para el lenguaje cinematográfico,

\footnotetext{
${ }^{1}$ Silveira, Estevan - nome artístico, produtor e diretor cinematográfico, nascido em Curitiba - PR. Produziu e dirigiu mais de 30 filmes. Discente do curso de Mestrado Profissional do Programa de Pós - Graduação em Artes, turma - 2020 , Campus Curitiba II, da Universidade Estadual do Paraná (UNESPAR), com Pós-graduação em Produção e direção de documentários pelo Centro Universitário Curitiba (UNICURITIBA). https://orcid.org/0000-0002-2236-0635. estevan_silveira@hotmail.com

2 Doutora e Mestre em Letras pela Universidade Estadual do Oeste do Paraná - UNIOESTE; Mestre em Educação pela Universidade Estadual de Ponta Grossa - UEPG. Reitora da Universidade Estadual do Paraná - UNESPAR, Docente do Mestrado Profissional em Artes - PPGARTES/UNESPAR. Líder do Grupo de Pesquisa CNPq: Cinema brasileiro e Educação. http://lattes.cnpq.br/1331036846713013.https://orcid.org/0000-0001-9198-1235. saletems@uol.com.br
} 
de la película documental helada. Las relaciones intersemióticas entre texto literario y texto cinematográfico se abordan en este artículo, con el objetivo de revisar tanto la traducción entre lenguajes literales y cinematográficos como su inconmensurabilidad cognitiva.

Palabras clave: cine, cuento, Dalton Trevisan, semiótica.

\section{A literatura}

Assim tem início um dos contos mais famosos do escritor Dalton Trevisan ${ }^{3}$ :

Curitiba, que não tem pinheiros, esta Curitiba eu viajo. Curitiba onde o céu azul não é azul, Curitiba que viajo. Não a Curitiba para inglês ver, Curitiba me viaja. Curitiba cedo chegam as carrocinhas com as polacas de lenço colorido na cabeça - galiii-nhaóóó-vos - não é a protofonia do Guarani? Um aluno de avental branco discursa para a estátua do Tiradentes... (TREVISAN, 1979, p.84)

Neste conto, o autor lamenta as mudanças registradas em sua cidade natal, além de narrar com nostalgia a saudade dos tipos que habitavam a cidade, alertando sobre os novos tempos que se aproximam. De forma irônica, o autor ainda procura pequenas soluções para o futuro da cidade que ele acredita não mais existir.

De acordo com as notas da professora Berta Waldman ${ }^{4}$, em seu texto sobre o citado conto, segue este comentário sobre a Curitiba de Trevisan: "Erigida como o negativo da imagem apocalíptica, Curitiba é a representação do mundo que o desejo rejeita: o mundo do pesadelo, do cativeiro da agressão, Ventre de um Minotauro voraz, Curitiba organiza-se não como um caminho reto, a estrada que leva a Deus, mas como o labirinto, a imagem da direção perdida, que prende os passos de seus habitantes, impossibilitados de seguir em frente". (WALDMAN, 1989)

Outro ponto a ser ressaltado, trata-se da melancolia do texto em relação aos locais quase turísticos. Entenda-se, neste conto, que tal questionamento aborda alguns pontos conhecidos da cidade que deixaram de fazer parte dela, assim como alguns personagens e costumes antigos. Segundo José Castello ${ }^{5}$, que traça um perfil do escritor Dalton Trevisan, em algumas obras e principalmente em artigos jornalísticos, podemos considerá-lo um obcecado em fustigar a imagem sagrada da cidade: "Dalton escreve contra a Curitiba real" (CASTELLO, 1999, p. 239).

Dalton escreve, com melancolia, sobre uma cidade que não mais existe, ressaltando também com pesar a realidade de uma outra cidade que surgiu, em substituição àquela da qual o escritor se tornou um grande admirador e defensor. Em resumo, Trevisan é um dos únicos escritores nascidos na cidade de Curitiba e, sendo assim, ele a defende incansavelmente do caos futurista que o assombra.

Escritor, com formação em Direito pela Faculdade de Direito do Paraná, onde liderou um grupo literário, Dalton Trevisan publicou, entre 1946 e 1948, uma revista literária de nome Joaquim ${ }^{6}$. E é

\footnotetext{
3 Trevisan, Dalton J. Escritor brasileiro nascido na cidade de Curitiba no ano de 1925, famoso por seus livros de contos, dentre eles $O$ Vampiro de Curitiba. Avesso a entrevistas, motivo pelo qual ficou conhecido como o Vampiro de Curitiba.

${ }^{4}$ Doutora em Letras, pela Universidade de São Paulo, em que é livre-docente, autora de vários livros e especialista na literatura de Dalton Trevisan.

${ }^{5}$ José Guimarães Castello Branco (1951) é um escritor, jornalista e crítico literário brasileiro.

${ }^{6}$ Revista literária, publicada entre 1946 / 1948 na cidade de Curitiba, fundada por Dalton Trevisan, que foi realizada para divulgar a agitação cultural da época ( geração de 45 ), que totalizou 21 edições e com contribuições de grandes artistas como : Poty Lazarotto, Antonio Cândido, Mário de Andrade, Otto Maria Carpeaux, Carlos Drummond de Andrade, Wilson Martins, Euro Brandão, Temístocles Linhares, José Paulo Paes, Candido Portinari, Di Cavalcanti, Vinicius de Moraes, Sérgio Milliet, Heitor dos Prazeres, entre outros.
} 
nestas publicações que encontramos um rico material de seus primeiros livros. Onde em 1954 publicou, entre outros, o Guia Histórico de Curitiba e Crônicas da Província de Curitiba, edições populares, que lembram muito a literatura de cordel, conhecida em todo o Brasil. Foram destas obras, que mais tarde surgiriam as ideias trabalhadas no conto: "Em busca de Curitiba perdida".

Ao observar os habitantes da cidade, Dalton criou personagens e situações de significado universal, narrando suas histórias de forma concisa e em uma linguagem totalmente pessoal, de fato única. Avesso a entrevistas e demais exposições na mídia, Trevisan acabou por receber a alcunha de "Vampiro de Curitiba", nome de um de seus livros mais famosos. Considerado, segundo a crítica literária brasileira, um dos maiores contistas que o Brasil já revelou, Trevisan é referência, embora se negue a receber o título, devido a seu cabotinismo explicito. $O$ autor que se destaca pela concisão de seus textos, sendo um verdadeiro representante da face modernista da literatura brasileira, com uma obra pautada no registro do pequeno mundo da classe média miserável dos marginais que vivem na cidade.

Publicou várias obras primas da literatura, eleito por sua produção o vencedor do Prêmio Camões de 2014, ano em que também agraciado com o Prêmio Machado de Assis, pelo conjunto de sua obra. Sem dúvida, é dono dos melhores contos da atualidade, dentre os quais se encontram histórias que falam sobre a cidade de Curitiba, e que se tornaram uma síntese dos conceitos hoje reconhecidos como as histórias de personagens que vivem à margem de nossa sociedade.

O processo literário desenvolvido por Trevisan, a cada edição de sua obra, é o trabalhoso exercício de reescrever exaustivamente o mesmo conto. Como ocorre com o conto que foi publicado pela primeira vez com o título Minha cidade, de 1946, para ser relançado em 1992, como Em Busca de Curitiba Perdida, passando por outras versões, como a de 1953 (Guia Histórico de Curitiba, cordel do autor) e a de 1968, no livro Mistérios de Curitiba, ocasião em que o escritor trabalhou o texto em tom de manifesto, como exercício constante do processo de modernização de sua escrita. As várias versões produzidas por Trevisan deixam claras as pistas sobre a tarefa árdua que é o ato da criação literária. O título do conto, Em Busca de Curitiba Perdida, é uma referência ao livro do romancista francês Marcel Proust (1871/1922), lançado em 1913, intitulado: Em Busca do Tempo Perdido.

Em um artigo no periódico da revista digital da UFPR, o escritor Roberto NICOLATTO (2004) se refere a este conto de Trevisan, fazendo uma comparação com um dos capítulos de um conhecido livro do escritor italiano Ítalo Calvino, As cidades invisíveis, em que relaciona a memória da cidade como diretamente vinculada aos acontecimentos humanos, "nas simples marcas deixadas em cada segmento riscado por arranhões, serradelas, entalhes, esfoladuras", ou na "dimensão simbólica que à memória se confere, no tempo passado que se presentifica". Porém, para Dalton Trevisan, o espaço da cidade está sempre presente, mesmo que de forma velada, nos contos de costumes, sob a forma da antítese entre sim e o não, da Curitiba que se afirma, para no final se contradizer.

São muitos os escritores que tiveram em seus trabalhos uma relação com a cidade em que viveram, como Rubem Fonseca e o seu Rio de Janeiro, Jorge Amado e sua Bahia, Graciliano Ramos e o Nordeste brasileiro em seu Vidas Secas, as Minas Gerais de Pedro Nava, o Rio Grande do Sul de Mário Quintana, Guimarães Rosa com seu Grande Sertão: Veredas, assim na mesma forma vários outros escritores.

Dalton Trevisan, em seu Em Busca de Curitiba Perdida, traz a mesma visão saudosista de outros autores mundiais, fazendo emergir sua cidade da memória, por meio de diálogos com outros textos, trazendo referências a outras grandes obras, sempre dentro do espaço da mesma circularidade. $\mathrm{O}$ escritor opõe presente e passado, saudade e desapego, o confronto dos signos que representam suas memórias afetivas sobre a vida na cidade. Nenhum outro escritor curitibano conseguiu projetar o espaço urbano da cidade para fora de suas fronteiras, ao modo como se deu com o Nordeste de Graciliano Ramos ou o sertão de Guimarães Rosa. 
O significado da redundância, da repetição excessiva do discurso que se torna a marca de sua escrita compõe seu estilo único e inconfundível, sem dúvida tornando-o um escritor sem igual.

Ainda em paralelo com As Cidades Invisiveis, do escritor italiano Ítalo Calvino, em que ele nos provoca a acreditar que a memória da cidade está diretamente relacionada aos acontecimentos humanos, podemos fazer esta relação com a narrativa de Trevisan sobre a cidade de Curitiba.

Dalton elege os elementos mais significativos desse inventário e delimita o que poderíamos chamar de sua "geografia pessoal da cidade", ainda que com novos títulos ou formatos, ele vai tentar reafirmar e consolidar o que foi dito no discurso original. (NICOLATTO, 2004)

Embora conhecido por seus contos, Dalton Trevisan é um escritor de grandes textos literários, que tem na cidade de Curitiba seu principal universo literário, como se fosse uma locação perfeita para seu gênio criativo. Outros já tentaram usar a cidade como este pano de fundo, alguns com êxito, mas outros nem tanto. Trevisan, porém, é incomparável em seu uso inconfundível de Curitiba. Segundo Olga Arantes Pereira (2009), "o cinema retira da literatura parte significativa da tarefa de contar histórias; a narratividade continua a ser o traço hegemônico da cinematografia, apesar da grande diferença entre a página de um livro e a tela branca do cinema".

\section{O cinema}

O cinema é a arte que agrega diversas outras expressões artísticas, tendo importante papel na representação social de distintos tempos históricos. Pelo seu potencial de materializar realidades vivenciadas pelos sujeitos sociais, a linguagem cinematográfica ficcional ou documental, se torna forte aliada na divulgação da literatura. O discurso fílmico, por meio da fruição estética, é capaz de suscitar no espectador sentimentos, emoções, bem como leituras críticas que culminam, inclusive, em novas formas de ver e estar no mundo.

Desde seu surgimento em 1895, com pouco mais de cento e vinte anos de existência, a produção do cinema avança de um material altamente dispendioso, para as novas tecnologias de captação e reprodução de imagem em digital, conseguindo alcançar com mais facilidade e baixo custo, as várias camadas sociais, ampliando sua capacidade de sedução e de suscitar a imaginação em seu receptor.

No Paraná, a filmografia e a história de seu cinema nasceram na primeira década do século XX, com trabalhos realizados em película por historiadores e fotógrafos que fizeram transpor para a tela a antiga ligação entre imagem e literatura.

Desde que foi inventado, o cinema artístico conquistou o mundo e fez nascer uma indústria, aplicando nas telas seu grande potencial de produzir histórias e narrativas. Por isso, até hoje ainda se perguntam se os livros seriam melhores que suas versões cinematográficas. Porém, a verdade é que algumas das melhores obras do cinema foram baseadas na literatura. As adaptações e a transposição cinematográfica são maneiras diferentes de contar uma história, tornando-se opções importantes para a criatividade artística. "Em um filme o que importa não é a realidade, mas o que dela possa extrair a imaginação". (Charles Chaplin, 1975)

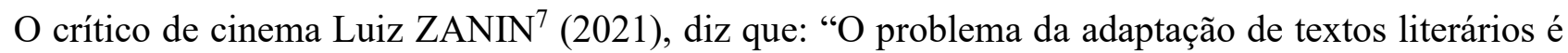
praticamente tão antigo quanto o cinema. Se este nasceu dividido entre o documental (Lumière) e a fantasia (Melliès), logo se colocou a questão ficcional como meta possível". Afinal, a "necessidade narrativa parece uma pulsão humana que remonta aos primórdios da espécie, quando as pessoas se reuniam em volta da fogueira para que alguém lhes contasse uma história".

\footnotetext{
${ }^{7}$ Luiz Zanin (1951), crítico de cinema brasileiro. 
Poucos foram os cineastas que tiveram êxito com o casamento entre cinema e literatura. Ainda mais se tratando de Trevisan, em que tudo é possível. O autor não aceita cortes ou alterações em seus textos, embora quando seus trabalhos são transportados para outra arte, como é o caso do teatro, se reveste de sucesso, especialmente com a direção de alguns autores e parceiros em várias peças de diferentes estilos.

Com o consentimento do autor, apenas um diretor de cinema transportou para as telas um filme de longa-metragem, onde costurou vários contos, como em uma colcha de retalhos, conseguindo a façanha de agradar ao contista. Este autor foi Joaquim Pedro de Andrade, com seu Guerra Conjugal ${ }^{8}$.

Em Guerra conjugal, a concisão e a repetição da escrita de Dalton Trevisan são mimetizadas pela insistência nos planos próximos e desenvolvidos em espaços fechados, sempre a captar relações amorosas pautadas pelo desejo de subjugar o outro, em consistente captação da atmosfera dos tempos militares. Os filmes de Joaquim Pedro são marcados, portanto, por aguda leitura de obras da literatura nacional, "transluciferadas" em intensos exercícios cinematográficos, sem que se abandone a reflexão sobre o país ou a sociedade brasileira, inegável obsessão do cineasta, expressa também de forma contundente na última de suas entrevistas. (FERREIRA, p.23, 2015)

Em seu estudo, Douglas FERREIRA (2015) descreve o esforço de Joaquim Pedro para ser fiel à obra original de Trevisan. Com o objetivo de respeitar ao máximo os contos escolhidos, Ferreira vai mais além desta análise e fala do processo criativo do cineasta, que mantém nesta obra um diálogo muito significativo com a literatura do contista: “...o modo como Joaquim Pedro traduziu os contos, ao reelaborar a literatura de Trevisan no interior de um gênero cinematográfico de amplo apelo popular, a pornochanchada, a cujos traços mais recorrentes o cineasta adere, em princípio, apenas para subvertê-los na sequência". Seu esforço pode ser traduzido como o respeito ao acordo feito pelo cineasta com o escritor.

Para as professoras Ana Maria CARLOS e Flávia PINATI (2010), "os cineastas viram a literatura, como uma grande fonte de inspiração, já que ambas as artes se baseiam na estrutura narrativa, possuindo como objetivo comum contar ou mostrar uma história". Ainda afirmam sobre as adaptações literárias que: "desta forma é que as relações entre literatura e cinema ora são marcadas por uma grande união e ora assinaladas por grandes disputas a respeito do julgamento de valor entre ambos. Uma das principais discussões que paira sobre essa atividade tão constante é a manutenção ou não dos aspectos que compõem a obra original". Em sua pesquisa, as autoras entram em uma discussão muito polemizada, em ambos os campos das artes, questões muito mais combativas pelo lado literário, do que o cinematográfico. Adaptar ou Transpor é uma discussão que vem tomando grandes proporções, tanto no Cinema, como na Literatura.

\section{A transposição cinematográfica}

Ao referir-se às adaptações cinematográficas, André Bazin (1918/1958) afirma que para passar das páginas para as telas, "o romance requer uma certa margem de criação para passar da escritura à imagem" (BAZIN, 1991, p. 83). Mas, para ele o maior problema das adaptações são o da vulgarização, e a culpa desta generalização é do comércio em que o cinema está envolvido, como aponta: "...que acusa um aumento surpreendente da venda das obras literárias depois da adaptação pelo cinema". (BAZIN, 1991, p. 93) Existem outras correntes que se opõem às adaptações literárias,

\footnotetext{
${ }^{8}$ GUERRA conjugal. Direção e Roteiro: Joaquim Pedro de Andrade. Baseado em contos e diálogos de Dalton Trevisan. Produção: Indústria Brasileira de Filmes e Filmes do Serro. Fotografia: Pedro de Moraes. Cenografia, figurinos e letreiros: Anísio Medeiros. Montagem: Eduardo Escorel. Música: Ian Guest. Elenco: Lima Duarte, Carlos Gregório, Jofre Soares, Carmem Silva, Ítala Nandi, Carlos Kroeber, Cristina Aché, Analú Prestes, Dirce Migliaccio, Elza Gomes, Maria Lúcia Dahl, Wilza Carla e Zélia Zemir. Ano: 1975. Longa - metragem em 35 mm, colorido, duração: 90 min.
} 
como as seguidas pelo crítico e cineasta francês, François Truffaut (1932/1984), que recebeu grande influência de Bazin.

Vários trabalhos cinematográficos de que participamos e que foram produzidos e transpostos para o cinema seguiram sempre pelo caminho da fidelidade, pois se um cineasta usa uma obra literária (conto ou romance) como base de seu trabalho cinematográfico, precisa ser fiel à narrativa, do contrário, escreva seu próprio roteiro. Nossa experiência com a transposição dos contos do escritor Dalton Trevisan são provas deste respeito.

Com sua autorização e supervisão transportamos para as telas do cinema vários contos, onde atuamos na produção, direção e como co-roteiristas, sempre buscando pela fidelidade à fonte literária. Foram exemplos deste casamento entre Literatura e Cinema, os contos de Trevisan: Ezequiel, realizado em 1995; Que Fim Levou o Vampiro de Curitiba?, de 1996; Retrato 3X4, realizado em 1997; O Escapulário, em 2001; Punhal na Garganta, em 2003; Penélope, em 2004; Balada do Vampiro, de 2006 (filme em $35 \mathrm{~mm}$ ); Fatal, finalizado em 2008. Posteriormente, ao reler e analisar sua obra, em 2008 realizamos o filme: Em busca de Curitiba perdida. Esta obra cinematográfica pode ser considerada a síntese da transposição para o cinema do olhar de Trevisan sobre a cidade de Curitiba. Projeto ousado, na medida em que transformamos uma ficção escrita pelo grande contista, em um filme do gênero documentário.

O filme Em busca de Curitiba perdida é uma trabalhosa transposição cinematográfica de um dos mais famosos contos do escritor paranaense Dalton Trevisan, que faz parte do livro Mistérios de Curitiba de 1968. O esforço cinematográfico desse trabalho deveu-se à fidelidade que guarda com o conto, uma atitude técnica desenvolvida a partir uma relação de cumplicidade com a literatura de Trevisan. Por essa razão é preciso conjugar o cinema no plural, pois se trata de uma arte coletiva, que abriga em si mesma outras artes.

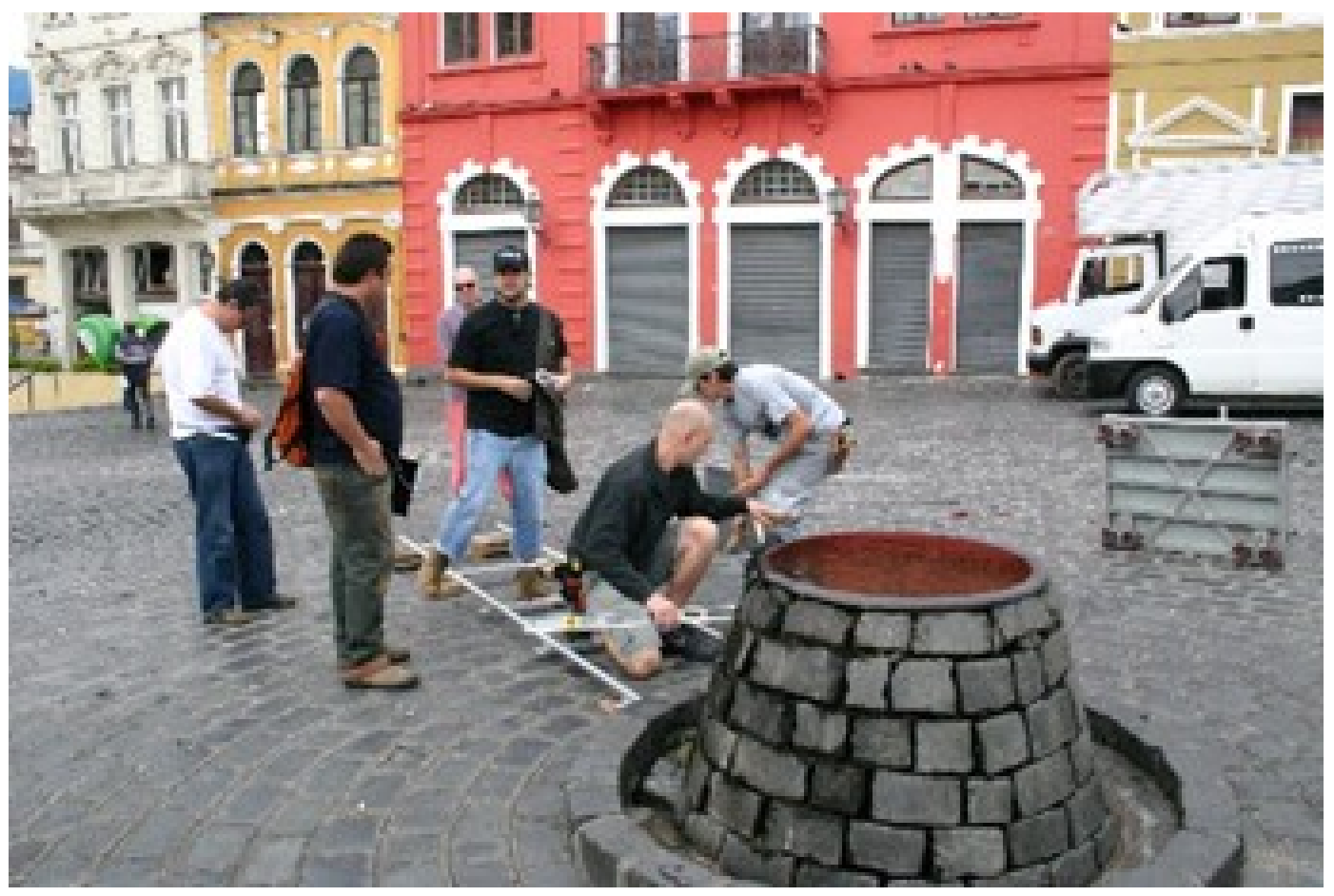

Figura 1: making of do filme.

O contato com a rica literatura de Trevisan nos proporcionou a compreensão do sofrimento alheio, assim como a arte de observar a natureza humana. Enxergar a vida e o tempo, aprendendo a saborear os fatos humanos com a paciência necessária para descrevê-los, seja em livros ou filmes. 
Em anexo segue a íntegra do conto de Dalton Trevisan.

\section{Discurso fílmico}

Os elementos deste discurso fílmico descrevem as primeiras cenas como representações da ideia de solidão, que podemos observar por meio da narração do conto, realizada na voz de um locutor, que vai ao encontro a esta transposição cinematográfica. Outra face deste discurso é a montagem realizada para atentar as impressões do saudosismo que sugere o conto e que nos traz à referência conceitos que Gilles Deleuze explora em seu livro Cinema I: a imagem - movimento (1983).

Uma análise deste filme pode ser realizada a partir de três recortes cruciais, sendo o primeiro deles um destaque dos registros iniciais desta película, que acompanha a imagem sugerida pelas primeiras frases do conto (07:37-01:38), em que é apresentada uma cena do marco inicial da cidade, passando pelos créditos e o título do filme, terminando exatamente na cena em que vemos uma panorâmica da cidade, imagem dos prédios como sendo uma metáfora da narração que fala de uma Curitiba sem pinheiros ou céu azul.

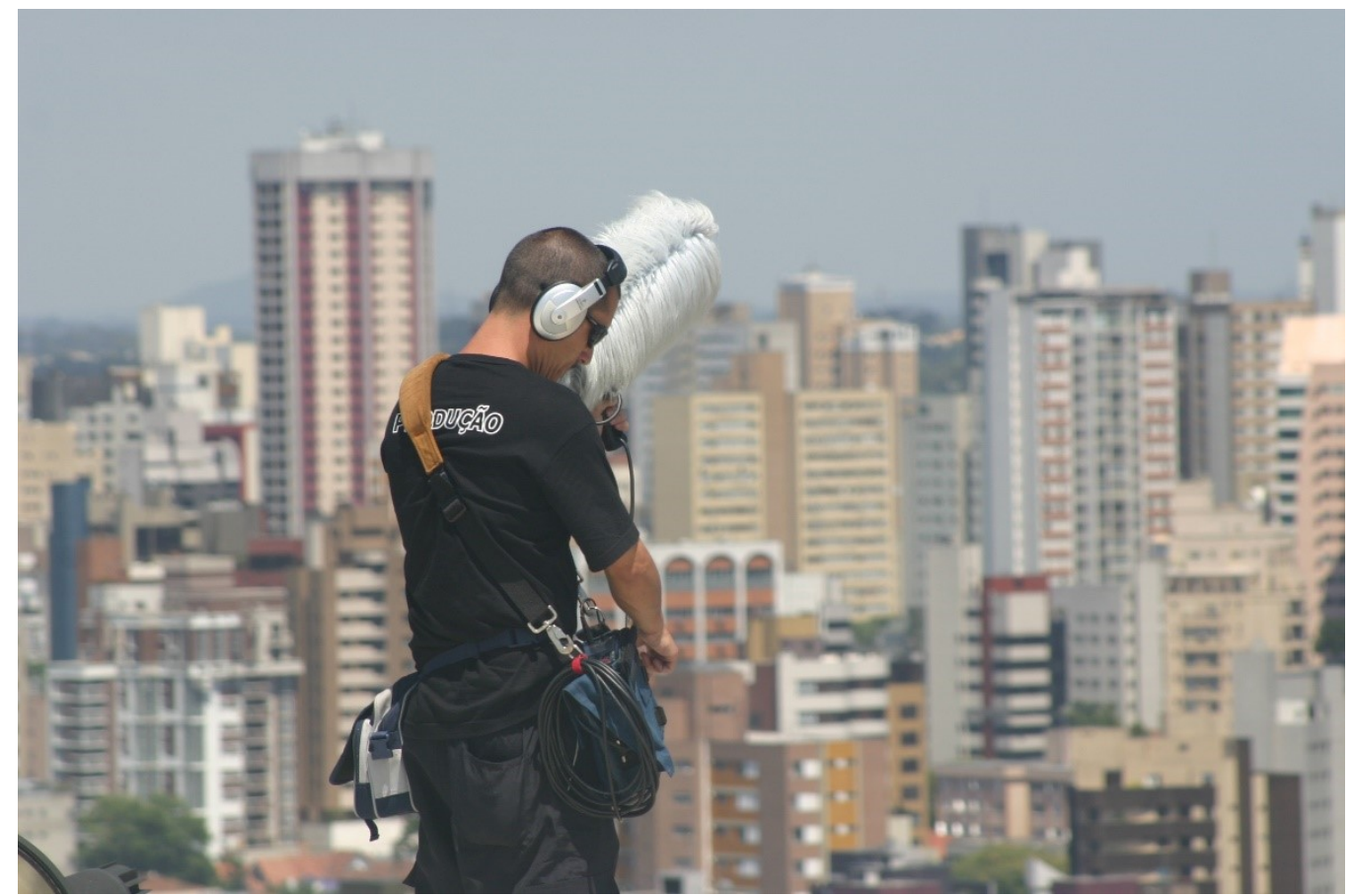

Figura 2: Curitiba sem pinheiros.

Voltamos ao discurso de Deleuze, em que ele faz uma análise da montagem, neste caso mobilizada através do discurso fílmico a que as imagens nos remete. Neste caso a câmera direciona nosso olhar para a introdução da história, que é acompanhada pela narração em off no filme, trazendo um ponto de vista da cidade, que apresenta uma urbe de concreto e que nada tem a ver com a cidade descrita pelo autor.

Em um segundo momento, quando o filme dá lugar a uma cena bucólica em que uma criança aparece brincando na janela com seu gatinho (04:18-04:55). A narração nos remete a uma cidade sem asfalto, com suas ruas de barro, talvez uma vida triste que contrasta com a primeira cena de uma cidade fria de cimento de concreto armado, em que se refere o autor . 


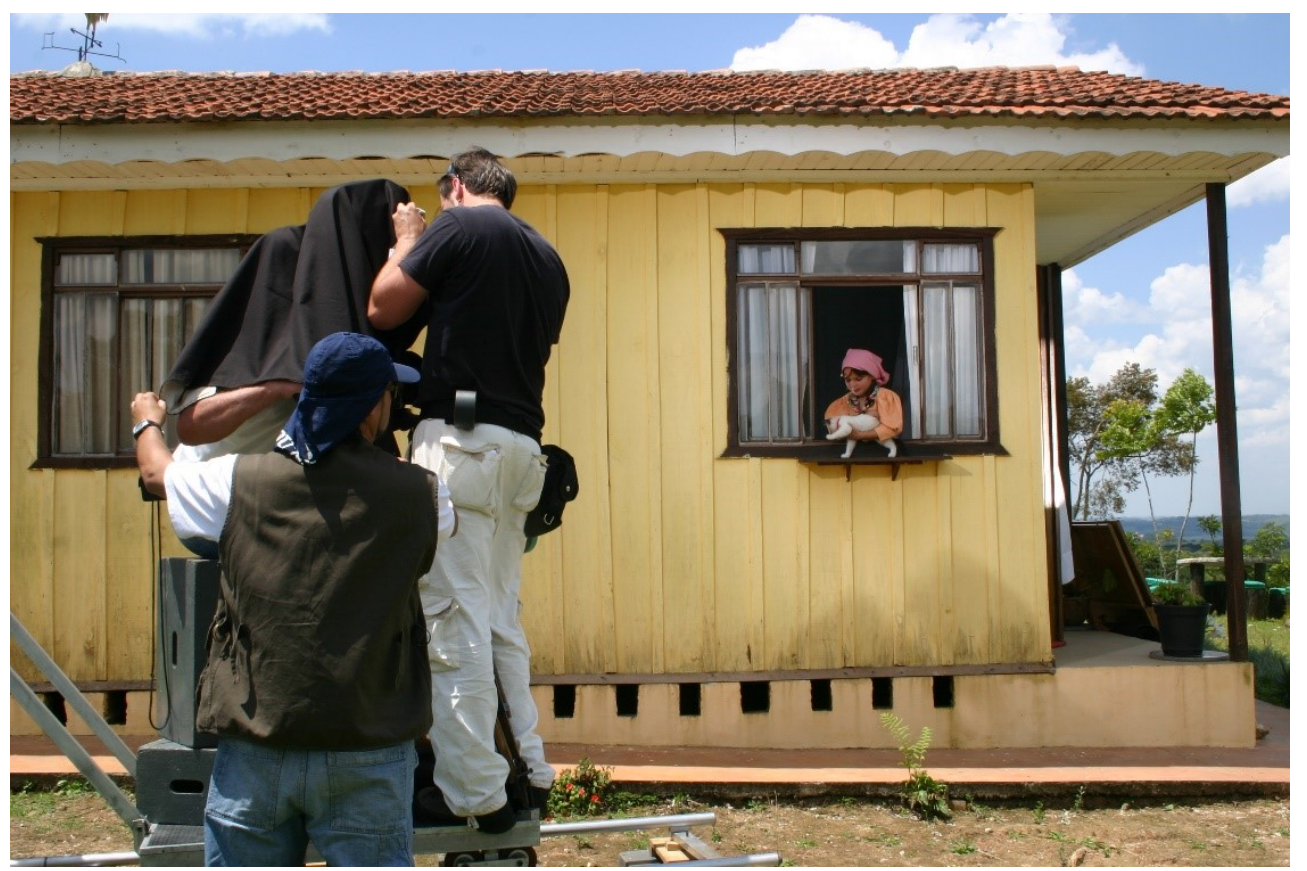

Figura 3: Criança com gato na janela.

E em seu terceiro momento, onde trazemos um recorte da cidade, mostrada através das cenas das ruinas de uma Curitiba perdida, como nos leva a pensar a narração do texto, que nos conduz junto com a cena final onde vemos uma carroça com a vendedora de ovos, solitária em companhia de sua filha, que neste caso pode refere - se a criança que brincava ingenuamente com seu gatinho, e que se vai pelas estradas de chão entre as fazendas dos bairros mais afastados da cidade determinado um vazio e uma solidão em que vive o escritor, apenas acompanhado por seu conto. Como diz a escritora Berta Waldman em seu estudo de 1989, com o título de DO VAMPIRO AO CAFAJESTE ; "Curitiba organiza-se não como um caminho reto, a estrada que leva a Deus, mas como o labirinto, a imagem da direção perdida, que prende os passos de seus habitantes, impossibilitados de seguir em frente". 


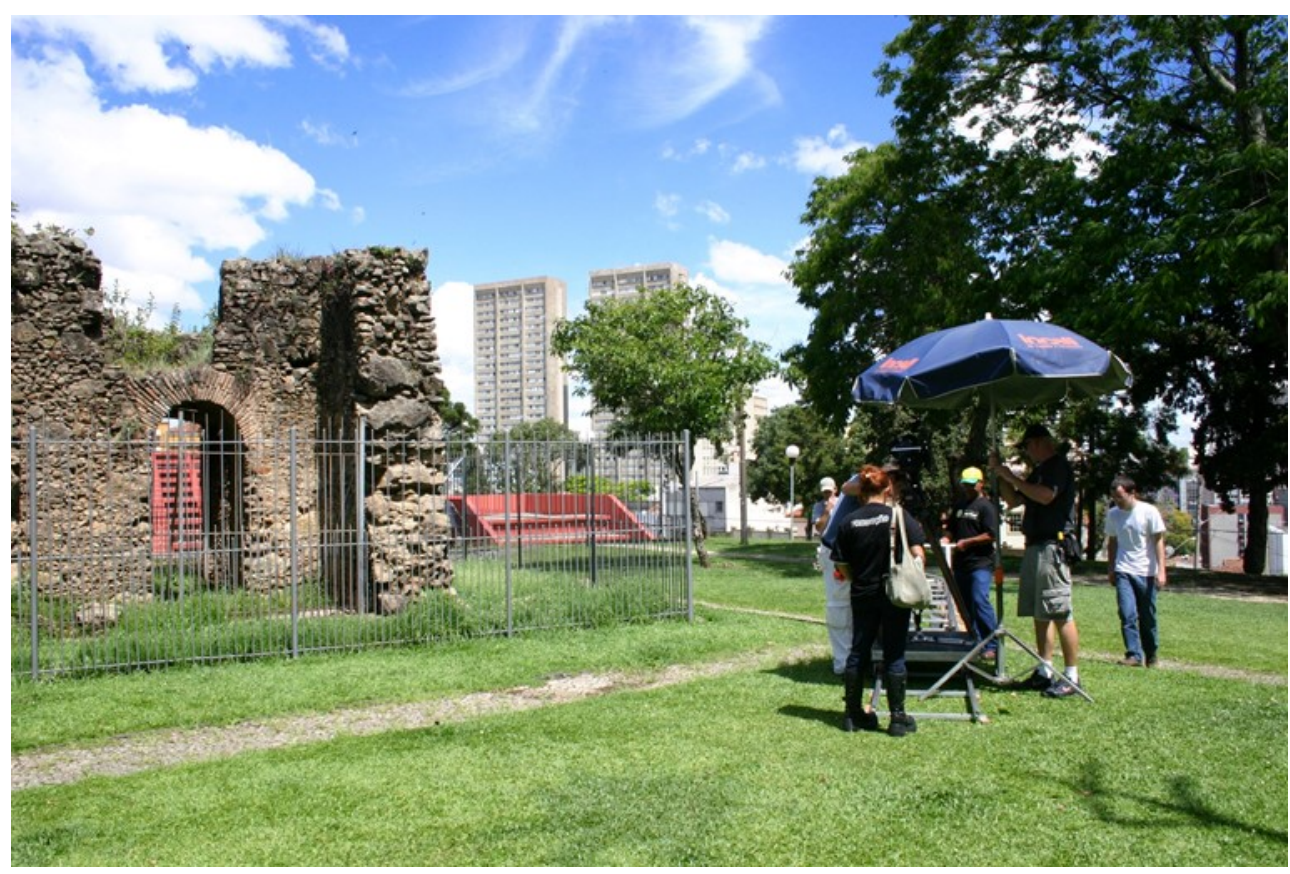

Figura 4: filmagens nas Ruinas de São Francisco, Curitiba.

\section{BIBLIOGRÁFIA}

BAZIN, André. O Cinema: Ensaios. São Paulo: Brasiliense, 1991.

CALVINO, Ítalo. As cidades invisíveis. São Paulo: Companhia das Letras, 1990.

CLARET, Martin. CHAPLIN: por ele mesmo. São Paulo - SP: livro Clipping; Editora Martin Claret Ltda, 2004.

CARLOS, Ana Maria e PINATI, Flávia. Das páginas às telas do cinema: a transposição do ponto de vista. Revista de Literatura, História e Memória; ISSN: 1983-1498 — ISSN: 1809-5313. Universidade Estadual do Oeste do Paraná ( Unioeste ). Cascavel / PR, 2010

ECO, Umberto. Viagem na Irrealidade cotidiana. Rio de Janeiro: Ed. Nova Fronteira, 1984.

DELEUZE, Gillles. Foucault. São Paulo: Brasiliense, 1991.

. Cinema I: a imagem-movimento. São Paulo: Brasiliense, 1983.

EISENSTEIN, Sergei. O Sentido do filme. Rio de Janeiro: Jorge Zahar, 1990.

FERREIRA, Douglas de Magalhães. Guerra conjugal: o cinema antropofágico de Joaquim Pedro de Andrade. 2015. 154 f. Dissertação (mestrado) - Universidade Estadual Paulista Júlio de Mesquita Filho, Faculdade de Ciências e Letras (Campus de Araraquara), 2015.

GUIA HISTÓRICO DE CURITIBA. Curitiba, 1953. p. 3.

MACHADO, Arlindo. Pré-cinemas \& pós-cinemas. Campinas: Papirus, 1997.

NICOLATTO, R. Em busca de Curitiba perdida: resistência...Revista Letras, n. 64, p. 125-141. Editora UFPR, Curitiba / PR, 2004. 
PEREIRA, Olga Arantes. Cinema e Literatura: dois sistemas semióticos distintos. Kalíope, Revista do Programade Estudos Pós - Graduados em Literatura e Crítica Literária da PUC / SP. ISSN: 18086977. V.12, n.24, 2016.

TREVISAN, Dalton. Minha cidade. Joaquim, Curitiba, n. 6, p. 18, nov. 1946. Edição fac-similar.

. Em busca de Curitiba perdida. Rio de Janeiro: Record, 1992.

ZANIN, Luiz. Blog Cinema, cultura \& Afins. Estado de S. Paulo. Site https://cultura.estadao.com.br/blogs/luiz-zanin/. Acessado em 01 de agosto de 2021.

\section{DADOS DO FILME}

\section{Título: EM BUSCA DE CURITIBA PERDIDA}

Filme : 35mm / Gênero: documentário / Tempo de Duração : 13 min., 57 s.

Direção: Estevan Silvera / Produção Executiva: Making \& Off produções

Ficha Técnica: direção ESTEVAN SILVERA argumento e roteiro DALTON TREVISAN produção ESTEVAN SILVERA / MARLENE SERAPHIM assistente direção MARCOS S. SABÓIA / PEDRO MEREGE direção de fotografia /câmera RUBENS ELEUTÉRIO $1^{\circ}$ ass. Câmera ALVARO ARCHANJO JR. $2^{\circ}$ ass. Câmera HENRIQUE RIBEIRO montagem PEDRO MEREGE / MARCOS S. SABÓIA ass. Produção ADALGISA LACERDA / JOAQUIM SARMENTO / MARCOS PAULO / PATRINE ALVES / RAPHAEL STELLA still ENÉAS GOMEZ direção de arte MIGUEL JARDINEIRO maquiagem / cabelos JEAN LOUIS figurinos MARIA ELISA TROTTA TELLES direção de atores LAIRCE SCREMIN som direto ROBERTO CARLOS DE OLIVEIRA trilha sonora /edição e mixagem GILBERTO ZANELATTO ( BETINHO) narração IVO RODRIGUES eletricistas ODAIR DA SILVA / ARNALDO GABARDO maquinaria LUCIANO OLIVA / ADRIANO / MARCELO / ANTONIO MARÇALO estagiário MARCOS P. RODRIGUES elenco CURITIBANOS QUE NASCERAM E VIVEM NA CIDADE.

Link do filme: https:/www.youtube.com/watch?v=_bcPi9aMeks 


\title{
EM BUSCA DE CURITIBA PERDIDA
}

\author{
Dalton Trevisan
}

Curitiba, que não tem pinheiros, esta Curitiba eu viajo. Curitiba, onde o céu azul não é azul, Curitiba que viajo. Não a Curitiba para inglês ver, Curitiba me viaja. Curitiba cedo chegam as carrocinhas com as polacas de lenço colorido na cabeça - galiii - nha - óóó - vos - não é a protofonia do Guarani? Um aluno de avental branco discursa para a estátua do Tiradentes.

Viajo Curitiba dos conquistadores de coco e bengalinha na esquina da Escola Normal; do Gigi, que é o maior pidão e nada não ganha (a mãe aflita suplica pelo jornal: Não dê dinheiro ao Gigi); com as filas de ônibus, às seis da tarde, ao crepúsculo você e eu somos dois rufiões de François Villon.

Curitiba, não a da Academia Paranaense de Letras, com seus trezentos milhões de imortais, mas a dois bailes no 14, que é a Sociedade Operária Internacional Beneficente O 14 De Janeiro; das meninas de subúrbio pálidas, pálidas que envelhecem de pé no balcão, mais gostariam de chupar bala Zequinha e bater palmas ao palhaço Chic - Chic; dos Chás de Engenharia, onde as donzelas aprendem de tudo, menos a tomar chá; das normalistas de gravatinha que nos verdes mares bravios são as naus Santa Maria, Pinta e Niña, viajo que me viaja.

Curitiba das ruas de barro com mil e uma janelinhas e seus gatinhos brancos de fita encarnada no pescoço; da zona da Estação em que à noite um povo ergue a pedra do túmulo, bebe amor no prostíbulo e se envenena com dor de cotovelo; a Curitiba dos cafetões - com seu rei Candinho - e da sociedade secreta dos Tulipas Negras eu viajo.

Não a do Museu Paranaense com o esqueleto do Pithecanthropus erectus, mas do Templo das Musas, com os versos dourados de Pitágoras, desde o Sócrates II até os Sócrates III, IV e V; do expresso de Xangai que apita na estação, último trenzinho da Revolução de 30, Curitiba que me viaja.

Dos bailes familiares de várzea, o mestre-sala interrompe a marchinha se você dança aconchegado; do pavilhão Carlos Gomes onde será HOJE! SÓ HOJE! apresentado o maior drama de todos os tempos - A Ré Misteriosa; dos varredores na madrugada com longas vassouras de pó bem os viralatas da lua.

Curitiba em passinho floreado de tango que gira nos braços do grande Ney Traple e das pensões familiares de estudantes, ah! que se incendeie o resto de Curitiba porque uma pensão é maior que a República de Platão, eu viajo.

Curitiba da briosa bandinha do Tiro Rio Branco que desfila aos domingos na Rua 15, de volta da Guerra do Paraguai, esta Curitiba ao som da valsinha Sobre as Ondas do Iapó, do maestro Mossurunga, eu viajo.

Não viajo todas as Curitibas, a de Emiliano, onde o pinheiro é uma taça de luz; de Alberto de Oliveira do céu azulíssimo; a de Romário Martins em que o índio caraíba puro bate a matraca, barquilhas duas por um tostão; essa Curitiba merdosa não é a que viajo. Eu sou da outra, do relógio na Praça Osório que marca implacável seis horas em ponto; dos sinos da Igreja dos Polacos, lá vem o crepúsculo nas asas de um morcego; do bebedouro na pracinha da Ordem, onde os cavalos de sonho dos piás vão beber água.

Viajo Curitiba das conferências positivistas, eles são onze em Curitiba, há treze no mundo inteiro; do tocador de realejo que não roda a manivela desde que o macaquinho morreu; dos bravos soldados 
do fogo que passam chispando no carro vermelho atrás do incêndio que ninguém não viu, esta Curitiba e a do cachorro-quente com chope duplo no Buraco do Tatu eu viajo.

Curitiba, aquela do Burro Brabo, um cidadão misterioso morreu nos braços da Rosicler, quem foi? quem não foi? foi o reizinho do Sião; da Ponte Preta da estação, a única ponte da cidade, sem rio por baixo, esta Curitiba viajo.

Curitiba sem pinheiro ou céu azul, pelo que vosmecê é - província, cárcere, lar - , esta Curitiba, e não a outra para inglês ver, com amor eu viajo, viajo, viajo. 